\title{
Determinants of Corporate Philanthropy: A Case of Karachi Stock Exchange
}

\author{
Uzma Bashir $^{\circledR}$ \\ Pakistan Institute of Development Economics
}

\begin{abstract}
Corporate Philanthropy $(\mathrm{CP})$ has become increasingly important as a means of filling gaps in the provision of social services using Public-Private partnerships. Very little research exists on determinants and motives of $\mathrm{CP}$ in Pakistan. This paper utilizes data from the 2001-2011 Annual Reports of 234 firms listed on the Karachi Stock Exchange (KSE) to analyze the association of $\mathrm{CP}$ with different firm specific factors like firm size, firm visibility, labor intensity, firm's financial position (measured as profitability, leverage, cash and equivalent balance, and dividend payout), and the impact of natural disasters on $\mathrm{CP}$. Because this is the first study on this data set, we have employed exploratory data analysis techniques and carefully consider the impact of outliers and other non-standard features of the data. We have used Panel data analytic techniques as well as the Tobit model to analyze the associations between different firm specific factors and $\mathrm{CP}$. We found that firm size, prior profitability, and natural disaster have significant positive impact on $\mathrm{CP}$. We found no evidence that firms are using philanthropy for image creation. Furthermore, exploratory data analysis shows that there are some clusters of firms, which behave differently. Standard regression analysis techniques cannot deal with such cases that require more sophisticated treatment.
\end{abstract}

Key words: Philanthropy, Firm Size, Natural Disaster, Clusters

JEL Classifications: D64, L11, Q54, C38

\section{INTRODUCTION}

Slow progress on the modest Millennium Development Goals demonstrates the lack of effectiveness of governments at providing social services. At the same time, corporate greed has been blamed for many evils, including the global financial crisis of 2008. The idea of corporate social responsibility (CSR) has been revived as a way of improving the tarnished image of corporations, especially large multinationals. Today large multinationals make more money than the GDP of most countries; the gap between the demand and supply for Social Services could possibly be fulfilled by corporate philanthropy, and thus, public private partnerships deserve serious attention.

Some economists, notably Milton Friedman and his followers, have argued that the only business of business is to make profits. Friedman (1970) asserted that "there is one and only one social responsibility of business - to use its resources and engage in activities designed to increase its profits so long as it stays within the rules of the game, which is to say, engages in open and free competition without deception or fraud." This view is also known as "shareholder theory". As opposed to shareholder theory there is stakeholder theory, which states that the "success of an organization depends on the extent to which the organization is capable of managing its relationships with key groups, such as financers and shareholders, but

(B) Uzma Bashir, PhD scholar, Department of Economics, Pakistan Institute of Development Economics, Islamabad, (uzma.economist@gmail.com). 
also customers, employees, and even communities or societies" (Van Beurden and Gössling, 2008, p. 408). The debate between these two opposing viewpoints was re-kindled after the Global Financial Crisis, which appeared to discredit the dominant shareholder theory; see Tse (2011) for a review. Despite the debate, current consensus supports "strategic philanthropy": firms use philanthropy for creating good image in the society and to gain competitive advantage, in parallel with societal development.

The concept of CP and CSR gained a lot of popularity, especially after observing the lot of environmental and human distress caused by pursuit of profits, unconstrained by social responsibility, in adherence to a narrow view of the shareholder perspective. As a result, firms faced extreme pressure from stakeholders to behave responsibly. These pressures resulted in a large body of research conducted on the issue of "corporate philanthropy", "corporate social responsibility", "corporate social investment", "strategic philanthropy", "corporate governance" etc. However, most of the research is based on data from US and UK. In Pakistan very few attempts have been made to investigate the correlates and determinants of CP. Some research has been conducted by the Pakistan Center of Philanthropy (PCP). PCP regularly conducts surveys to find out the situation of $\mathrm{CP}$ in Pakistan. In academic literature, Makki and Lodhi (2008) first investigated this issue in Pakistan. They found that advertisement intensive, large, and profitable firms contribute significantly more. We cannot, however, generalize their findings for Pakistan due to the small sample size ${ }^{1}$.

Many studies have found that besides firm size, profitability, and advertising intensity, there are certain other factors that may affect a firm's behavior regarding voluntary contributions like cash flow availability, dividend payout, leverage, labor intensity, and natural disaster. In this study, we have considered 234 firms that are registered at the Karachi Stock Exchange (KSE), on which data is available from 2001-2011. Based on a fairly complete data set, we first employed exploratory data analysis techniques to understand the nature of data and carefully consider the impact of outliers and other non-standard features of the data. Besides exploratory analysis, we also employ the Tobit model and Panel data techniques to formally estimate the determinants of $\mathrm{CP}$.

The rest of this paper is organized as follows: Second section deals with a review of the literature and testable hypothesis. Third section deals with sample and data sources. The fourth section deals with our methodology. The fifth section presents our empirical results, and finally section six concludes the study.

\section{LITERATURE REVIEW}

Neoclassical economists have considered $\mathrm{CP}$ as an irrational behavior, but proponents of $\mathrm{CP}$ justified its rationality by presenting different theories like "profit maximization, altruism, social responsibility, and managerial utility" (Abzug and Webb, 1996, p. 2). The proponents of $\mathrm{CP}$ argued that regardless of the motives of the firm, CP will ultimately increase firm's sales and profits. For example, if firms have a profit maximization motive, then $\mathrm{CP}$ improves the firm's image in society via advertisement and serves as "reputational capital", hence increasing the firm's profit. If firms have an altruistic motive, even then CP enhances the company's goodwill, which ultimately increases its profits. They argued that even if firms do not advertise much, stakeholders still learn about the firm. Regarding corporate responsibility motive, they argued that if executives claim that they feel it is their responsibility to serve

\footnotetext{
${ }^{1}$ They have used LSE 25 index companies.
} 
society, even then it increases firm's profit, because socially responsible behavior improves employee morale, productivity, and the firm's goodwill in the society. Another approach studies CP in the context of managerial utility theory, where CP is an "agency problem". Managers use philanthropy for their prestige at the firm's cost, but philanthropy also improves the firm's image in the society. One possible way to handle the agency problem is that managers should be asked to minimize the cost of giving or to use it in such a way that it increases the firm's profit ${ }^{2}$.

The literature on this topic, reviewed below, provides a huge list of factors that may determine a firm's level of giving. Due to constraints and limitations of the data available, we have only been able to focus on some of the main factors. In particular, we studied how CP and CSR are affected by firm size, firm visibility, labor intensity, leverage, profitability, cash and equivalent balances, dividend payout, and natural disaster. Before turning to the data analysis, we discuss how the literature frames the relationships between the variables under study and CP.

\subsection{Firm Visibility}

Literature suggest that high visibility firms contribute more (Brammer and Pavelin, 2006; Hull and Rothenberg, 2008; McWilliams and Siegel, 2001), because they have to maintain their image. Orlitzky et al. (2003) argued that advertisement and philanthropy both helps in creating image and competitive advantage by getting cheap and productive labor force (McWilliams and Siegel, 2001; Waddock and Graves, 1997) and enhance "customer loyalty"3. One interesting observation that supports this hypothesis is cited by Porter and Kramer (2002): the Tobacco Giant Philip Morris donated \$75 million in 1999 and then launched a $\$ 100$ million advertising campaign to publicize this ${ }^{4}$. Hence, we also expect that;

H1: High visible firms donate significantly more.

\subsection{Labor Intensity}

Some studies have also found that more labor intensive firms contribute significantly more (Brammer and Millington, 2008; Navarro, 1988), because it motivates workers and also helps firms in getting trained and educated work force, which increases firm profits. Hence we also expect;

$\mathrm{H} 2$ : There is positive association between $\mathrm{CP}$ and labor intensity.

\subsection{Firm's Financial Position}

Many empirical studies have found that financial constraint can influence a firm's philanthropic behavior; for example, firms facing high debt may donate less (Adams and Hardwick, 1998; Brammer and Millington, 2006; Millington, 2008; Seifert et al., 2004; Wang et al., 2008). Similarly, firms that are financially sound, having high cash flows, or earning high profits can easily allocate their resources towards social issues (Adams and Hardwick,

\footnotetext{
${ }^{2}$ For details, please see (Abzug and Webb, 1996)

${ }^{3}$ For details please see http://www.cof.org/files/documents/corporate grantmaking/measurement/nat_study customer.pdf

${ }^{4}$ Such behavior of firms raised the question whether firms actually want to serve the society or just pretending to serve the society but in fact use it for competitive advantage.
} 
1998; Brammer and Millington, 2008), while firms facing losses or those with limited cash donate less. Seifert et al. (2003), however, have argued that profitability is not a suitable variable; rather the level of available cash flows is a better measure to understand the actual position of business. Brammer and Millington (2008) and Seifert et al. (2003) have found positive association between $\mathrm{CP}$ and cash balances. Hence, there is no consensus in the literature that the measure of a firm's financial performance is positively associated with CP. Our study tries to investigate their association with $\mathrm{CP}$. On the basis of above discussion we can hypothesize as;

\section{H3: Leverage is negatively associated with $\mathrm{CP}$}

\section{$\mathrm{H} 4$ : Current profitability is positively associated with $\mathrm{CP}$}

H5: Cash and equivalent balances is positively associated with $\mathrm{CP}$

Some scholars have also argued that current profitability may not be the right factor that determines CP; instead of current profitability they found significant evidence in favor of prior profitability. They argue that in last year if the firm performs well, then it can easily engage in philanthropic activities (Arulampalam and Stoneman, 1995; Moore and Robson, 2002; Roberts, 1992; Ullmann, 1985). Hence, another possible research hypothesis could be;

H6: Prior profitability is positively associated with CP.

Some studies have also found a significant association between dividend payouts and CP but with mixed results. For instance, Navarro (1988) has found a positive association between dividend payouts and $\mathrm{CP}$, where paying high dividends indicates a firm's strong financial position, and if a firm is financially strong, it can easily allocate its resources towards social issues. Whereas Brammer and Millington (2008) have found a negative association between $\mathrm{CP}$ and dividend payouts, arguing that firms have to decide whether they pay more to their shareholders or stakeholders; if the firm pays more to shareholders in the form of dividends, then they face resource constraints that negatively influence donations, but if the firm is paying more to stakeholders, then they have less amount for shareholders. Hence, another possible research hypothesis could be;

H7: There is positive correlation between dividend payouts and $\mathrm{CP}$

H8: There is negative correlation between dividend payouts and $\mathrm{CP}$

\subsection{Firm Size}

Many empirical studies have found a positive association between firm size and CP like Adams and Hardwick (1998); Amato and Amato (2007); Brammer and Millington (2004, 2006); Carroll and Joulfaian (2005); Makki and Lodhi (2008). Large firms have enough resources (Johnson and Greening, 1999), trained administrative staff (Donaldson, 2001), and are facing more political pressure from government as well as from consumers (Roberts, 1992). Thus, large firms behave well to maintain their image in society (Thompson and Hood, 1993). Hence, we also expect;

H9: Positive association between $\mathrm{CP}$ and firm size. 


\subsection{Natural Disaster}

Different natural disasters like floods and earthquakes result in massive losses in the form of human and physical capital. In Pakistan massive destruction took place due to the 2005 Earthquake in Kashmir and the 2010 flood. Although firms operating in affected areas also faced heavy losses, it has been observed that firms still engage in humanitarian activities (Muller and Kräussl, 2011) that help them in strengthen their image (Godfrey et al., 2009; Hillman and Keim, 2001; Schnietz and Epstein, 2005) and financial position. Hence, we also expect;

H10: Firms make significant contributions at the time of natural disaster.

\section{SAMPLE AND DATA SOURCES}

In 2012, the number of total registered companies at KSE is 828; out of these 40 firms are registered as "Bonds", 132 are registered as "Future Contracts", three firms are registered as "Stock Index of Future Contract", 51 are registered as "Equity investment Instruments", and 43 are registered as "Financial Services". Following international studies, our study also excludes these corporations from the analysis, because they are not producing any real output. Hence, 559 firms remain for analysis, but from these 83 have been suspended, and 20 firms are newly registered. Moreover, data is missing for 222 firms, leaving only 234 firms available for our analysis. Our study focuses on data for these 234 firms from 2001 to 2011. Data has been collected from companies' annual reports. Annual reports have been collected from different sources like "companies' websites", "PakSearch.com: Data base company", and "KSE official website".

\section{METHODOLOGY}

Various methods have been observed in the literature like "at one extreme, Brown et al. (2008) runs 700 models, with 10,000 separate regressions, using 19 variables; at the other extreme, Campbell et al. (2002) do not use any regression model and simply describe linear changes over time" (Afshar, 2012, p. 71). Some studies have used Ordinary Least Square technique (Brown et al., 2006; Williams and Barrett, 2000). Most studies, however, have used either the Tobit model (Brammer and Millington, 2006; Brammer and Millington, 2008; Carroll and Joulfaian, 2005), or panel data techniques i.e., fixed effect model (FEM) and random effect model (REM; Chai, 2010; Gupta, 1996; Tilcsik and Marquis, 2013). "The ordinary least squares (OLS) method is not appropriate, because it does not correct for withinfirm autocorrelation and cross-sectional heteroscedasticity" (Chai, 2010).

We have divided the analysis into two stages; in the first stage we employed the exploratory data analysis technique to understand the nature of the relationship between different factors and CP. In the second stage we employed the Tobit model and REM.

\section{EMPIRICAL MODEL}

\subsection{Fixed and Random Effect Model}

FEM is used when there is correlation between unobserved effect and explanatory variables, while REM is used otherwise. Hausman test is normally used to decide whether difference in the coefficient is following any systematic pattern or not; if $p$ value is less than 5\% then FEM 
is used. However, it is generally believed that REM is more efficient, because of a smaller standard error and higher statistical power (Hsiao, 2003). Furthermore, when the number of cross-sections is large, the loss of degree of freedom is quite high (Gujarati, 2009) ${ }^{5}$, and thus in this situation REM is more appropriate. REM can be written as;

and

$$
Y_{i t}=\beta_{0}+X_{i t} \beta+\mu_{i}+\varepsilon_{i t}
$$

$$
Y_{i t}=\beta_{0}+X_{i t} \beta+w_{i t}
$$

where, $w_{i t}=\mu_{i}+\varepsilon_{i t}$ and $t=1,2, \ldots, n, i=1,2, \ldots, N$

Error term $w_{i t}$ consists of individual specific error $\mu_{i}$ and combined time series and crosssectional error component $\varepsilon_{i t}$. Both error components are normally distributed with mean zero and variance $\sigma_{\mu}^{2}$ and $\sigma_{\varepsilon}^{2}$, respectively.

Similarly, $Y_{i t}$ is the dependent variable of $i$ firm over time $t . X_{i t}$ is the time variant $1 \times k$ regressor matrix, $\beta_{0}$ is firms intercept, which remain constant.

$$
\begin{gathered}
C P_{i t}=\beta_{0}+\beta_{1} D V D_{i t}+\beta_{2} F V I_{i t}+\beta_{3} S I Z_{i t}+\beta_{4} L B I_{i t}+\beta_{5} P B T A_{i t}+\beta_{6} L I V_{i t}+\beta_{7} C H_{i t} \\
+\beta_{8} D N A D_{t}+\beta_{9} L P B T A_{i t}+w_{i t}
\end{gathered}
$$

where $i=1,2, \ldots, 234 ; t=1,2, \ldots, 10$ of firm $i$ at period $t$

$C P_{i t} \quad=$ Corporate Philanthropy measured as ratio of firms donations ${ }^{6}$ to sales

$D V D_{i t} \quad=$ Dividend payout measured as total dividend as a proportion of total asset ${ }^{7}$

FVIit $=$ Firm visibility measured as ratio of advertisement expenditure to sales ${ }^{8}$

$S I Z_{i t} \quad=$ Size measured as log of total assets ${ }^{9}$

$L B I_{i t} \quad=$ Labor Intensity measured as ratio of total employment cost to sales ${ }^{10}$

$P_{B T A_{i t}}=$ Profitability measured as ratio of profit before tax to total assets ${ }^{11}$

$L I V_{i t} \quad=$ Leverage measured as total debt to equity ratio ${ }^{12}$

$\mathrm{CH}_{i t} \quad=$ Cash holding, measured as ratio of cash and equivalent balances to sales ${ }^{13}$

$D N A D_{t}=$ Dummy Shock/ natural disaster at period $\mathrm{t}$, measured as DNAD $=1$ if there is shock otherwise 0

$L P B T A_{i t}=$ Lag of PBTA (profitability) of firm $i$ at period $t$

\footnotetext{
${ }^{5}$ Hausman test shows that REM should be used, so we are here explaining only REM.

${ }^{6}$ In "Securities and Exchange Commission of Pakistan (SECP) requires all listed companies to disclose corporate donations in their profit \& loss accounts in compliance with part III, E-1 of schedule 4 of Companies Ordinance 1984" (Makki and Lodhi, 2008).

${ }^{7}$ Brammer and Millington (2008) has also used total dividend as a proportion of total asset to measure firm divident payout.

${ }^{8}$ Grullon et al. (2004) has also used advertising by sales as a measure of visibility.

9 Adams and Hardwick (1998); Brammer and Millington (2008) and others have used log of total assets to measure firm size.

${ }^{10}$ Brammer and Millington (2008); Navarro (1988) and others have also used ratio of total employment cost to sales to measure labor intensity.

${ }^{11}$ Brammer and Millington (2008) has also usedratio of profit before tax to total asset as a measure of firm profitability.

${ }^{12}$ Brammer and Millington (2008) has also useddebt to equity ratio as a measure of firm leverage.

${ }^{13}$ Brammer and Millington (2008) has also used cash and eqviualent balance to sales to measure cash flows.
} 


\subsection{Tobit Model}

Data on CP is always positive (greater or equal to zero), it cannot be negative. This implies that corporate donation is a censored variable, and it cannot take negative values. Many empirical studies have used the censored samples of firms that make donations (Navarro, 1988; Adams and Hardwick, 1998; Brammer and Millington, 2008). They believe if Ordinary Least Square technique is used in this case, it will not provide unbiased and consistent estimates. Hence, the most commonly adopted solution is to estimate the Tobit model via the maximum likelihood approach, which provides consistent and unbiased estimates.

The basic Tobit model estimated here takes the following form;

$$
Y_{i t}^{*}=X_{i t} \beta+\varepsilon_{i t}
$$

where $Y_{i t}^{*}$ is observed dependent variable $Y_{i t}$, and is generated if $X_{i t} \beta+\varepsilon_{i t}>0$ and is otherwise equal to zero. Hence, we can write it as;

$$
C_{i t}^{*}=X_{i t} \beta+\varepsilon_{i t}
$$

$i=1,2, \ldots, 234$ and $t=1,2 \ldots \ldots 10$ and $X i t$ is a vector of explanatory variables that we expect to be associated with $\mathrm{CP}$.

\section{RESULTS AND DISCUSSION}

\subsection{Exploratory Analysis}

To explore the data this study uses scatter plots, which are useful in understanding the nature of distribution, the relationship between two variables, and in identifying outliers. The scatter plot of all explanatory variables with $\mathrm{CP}$ is discussed below.

\subsubsection{Firm visibility and Corporate Philanthropy}

Literature cited earlier in context of hypothesis $\mathrm{H} 1$ suggests that high visibility firms donate more. However, we have found that majority of firms from highly variable levels of firm visibility are doing very low $\mathrm{CP}$; there is only one small cluster which depicts a strong positive relationship (shown by the true regression line after excluding low $\mathrm{CP}$ firms).

Hence if we exclude this small cluster from the analysis, then in fact there is no relationship between firm visibility and $\mathrm{CP}$ for the majority of the firms. However, simply fitting a regression line would lead to a misleading conclusion that visibility is a significant factor, because high leverage outliers in the small cluster distort the results, as depicted in Figure 6.1. The conclusion from our data analysis is that the hypothesis of association between visibility of firms and CP does not hold for a large majority of firms that do very little CP. These firms have highly variable levels of visibility despite not engaging in any $\mathrm{CP}$. Overall, we reject hypothesis H1 of Brammer and Pavelin (2006) Hull and Rothenberg (2008) and McWilliams and Siegel (2001); for the vast majority of the firms studied, CP remains very low, while visibility varies over a wide range. However, there is a small cluster of firms where these two variables are closely associated, as per hypothesis H1. It would be worthwhile to study real world factors that differentiate these two types of firms, as hypothesis $\mathrm{H} 1$ only holds for the second type of firms, which are a small minority in Pakistan. 
Figure 6.1 Firm visibility (FVI) and Corporate Philanthropy (CP)

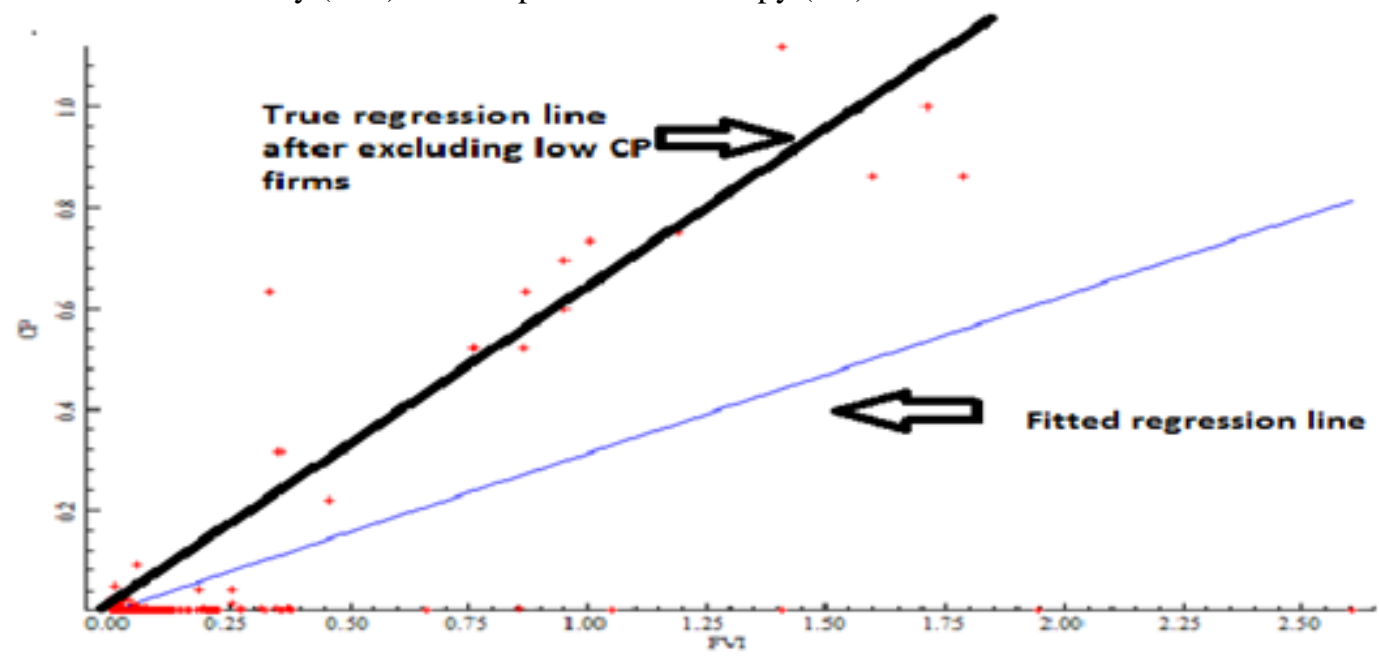

\subsubsection{Labor Intensity and Corporate Philanthropy}

Literature suggest that labor intensive firms donate more, but the scatter plot in Figure 6.2 shows that there is no relationship between labor intensity and $\mathrm{CP}$.

Figure 6.2 Labor intensity (LBI) and Corporate Philanthropy (CP)

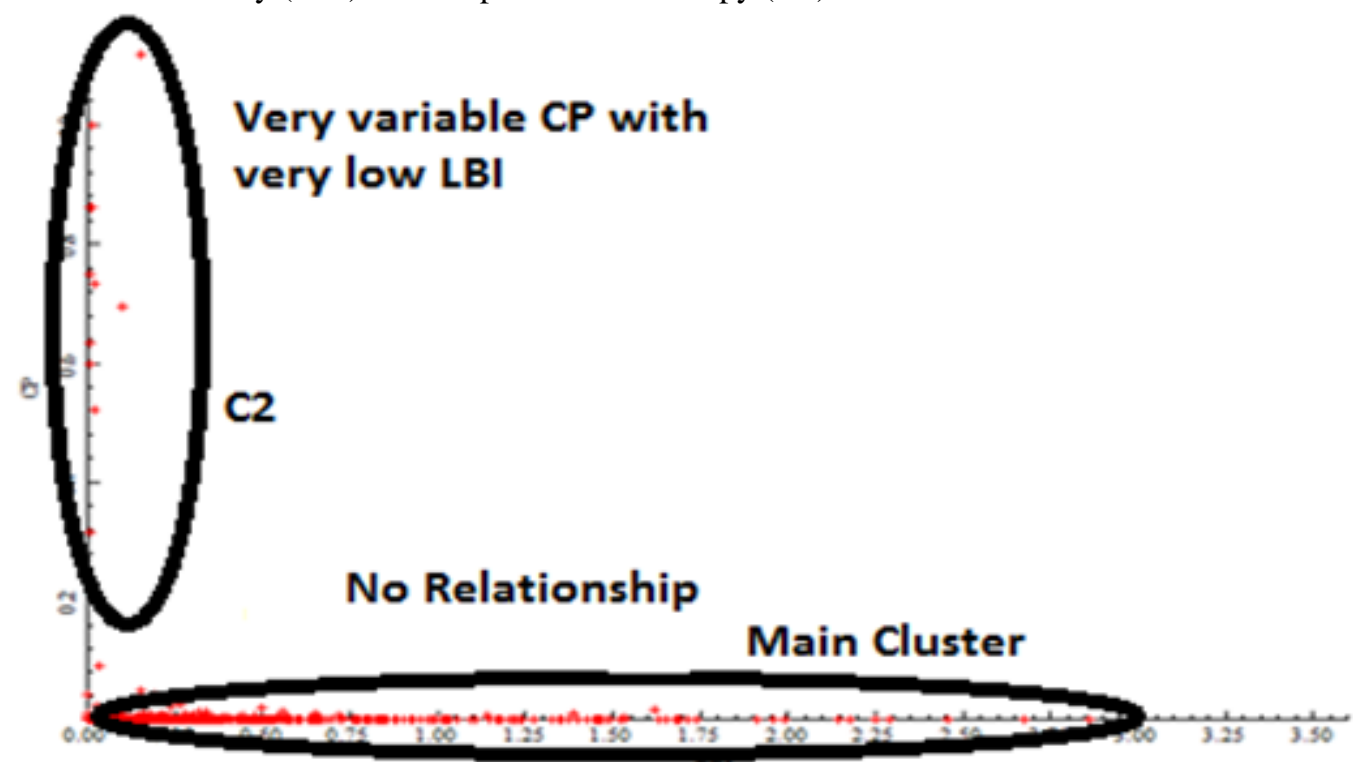

Basically there are two clusters, representing two different types of firms. The main cluster lies along the $\mathrm{x}$-axis, which consists of firms that have very low CP. This cluster is very spread out, so that these firms vary hugely in their labor intensity. Among these firms, labor intensity cannot be a determinant of $\mathrm{CP}$, since huge variations in LBI have no impact on $\mathrm{CP}$. A second smaller cluster (C2) represents a different category of firms all of which have very low labor intensity, but vary a lot in terms of their CP. As evident in Figure 6.2, variations in $\mathrm{CP}$ have no relationship with labor intensity in this category. Taking into account both clusters, we could say that there are two types of firms. One type is low on CP, and among these, the LBI is highly variable. A second type has very low LBI, but is very variable in terms of CP. It would be worthwhile to explore real world factors that differentiate these two 
types of firms. In any case, it is clear that hypothesis $\mathrm{H} 2$, as formulated by Brammer and Millington (2008) and Navarro (1988), is strongly rejected by the data.

\subsubsection{Leverage and Corporate Philanthropy}

Existing literature suggest that high leverage firms donate less, but Figure 6-3 shows that there is no association between leverage and CP. The scatter plot shows that there are two clusters. The main cluster shows very variable leverage at very low $\mathrm{CP}$, whereas cluster $\mathrm{C} 2$ shows very variable CP at almost same level of leverage. Together in both clusters, we don't see any relationship between leverage and CP. Taking into account both clusters, we could say that there are two types of firms. One type is low on CP, and among these, LIV is highly variable, whereas cluster $\mathrm{C} 2$ is very variable in $\mathrm{CP}$ at almost same level of leverage. Hence, it would be worthwhile to explore real world factors that differentiate these two types of firms. In any case, it is clear that hypothesis H3, as formulated by Adams and Hardwick (1998), Brammer and Millington (2006, 2008), Seifert et al. (2004), Wang et al. (2008) is strongly rejected by the data.

Figure 6.3 Leverage (LIV) and Corporate Philanthropy (CP)

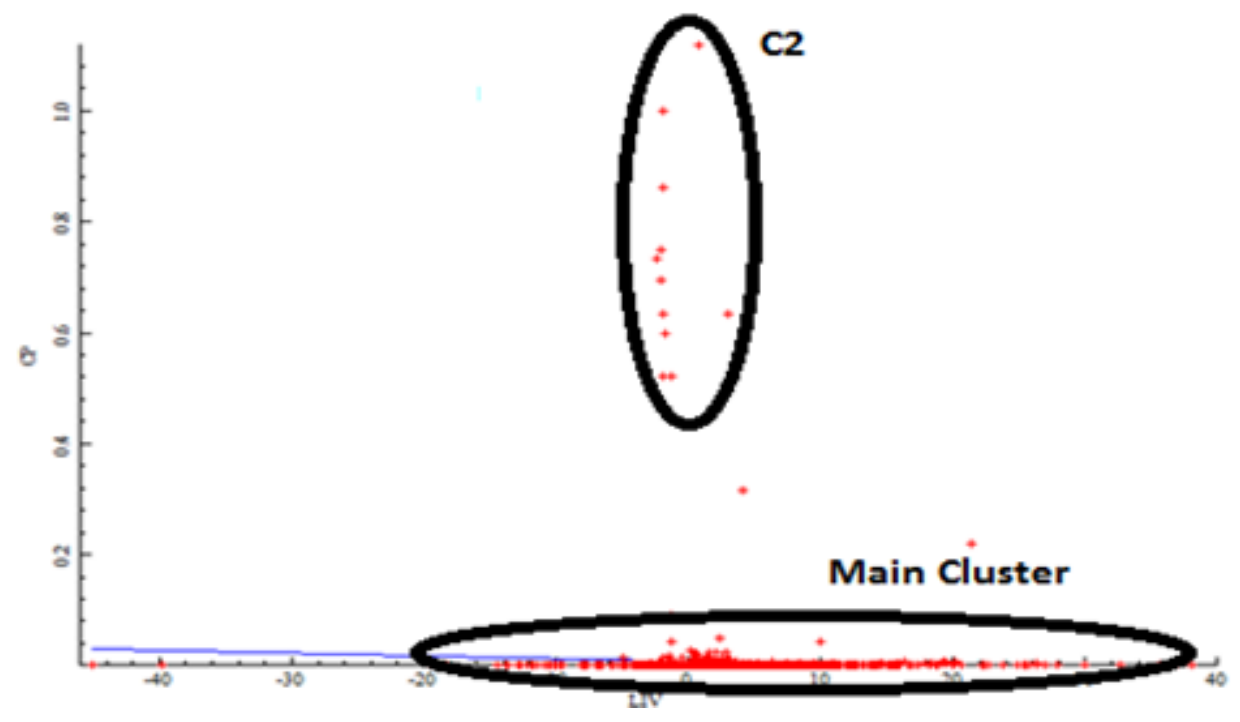

\subsubsection{Profitability and Corporate Philanthropy}

Adams and Hardwick (1998) and Brammer and Millington (2008) argued that firms with high profits are more likely to donate more. However, the scatter plot in Figure 6.4 shows that in general, this hypothesis does not hold for Pakistan. There are two clusters; C2 shows a wide range of variation in $\mathrm{CP}$ for nearly the same profit, while the main cluster shows low $\mathrm{CP}$ with a very wide range of profitability. Nonetheless, a standard regression leads to a positive relationship between profitability and $\mathrm{CP}$, because there is a high leverage outlier as shown in Figure 6-4, which is pushing the regression line upward. Hence, it's important to note that if we ignore outliers then it could lead to misleading results. Overall, the data strongly rejects the hypothesis H4 formulated by Adams and Hardwick (1998) and Brammer and Millington (2008). However, it would be worth exploring why some firms are making high donations at almost the same level of profitability. 
Figure 6.4 Current Profitability (PBTA) and Corporate Philanthropy (CP)

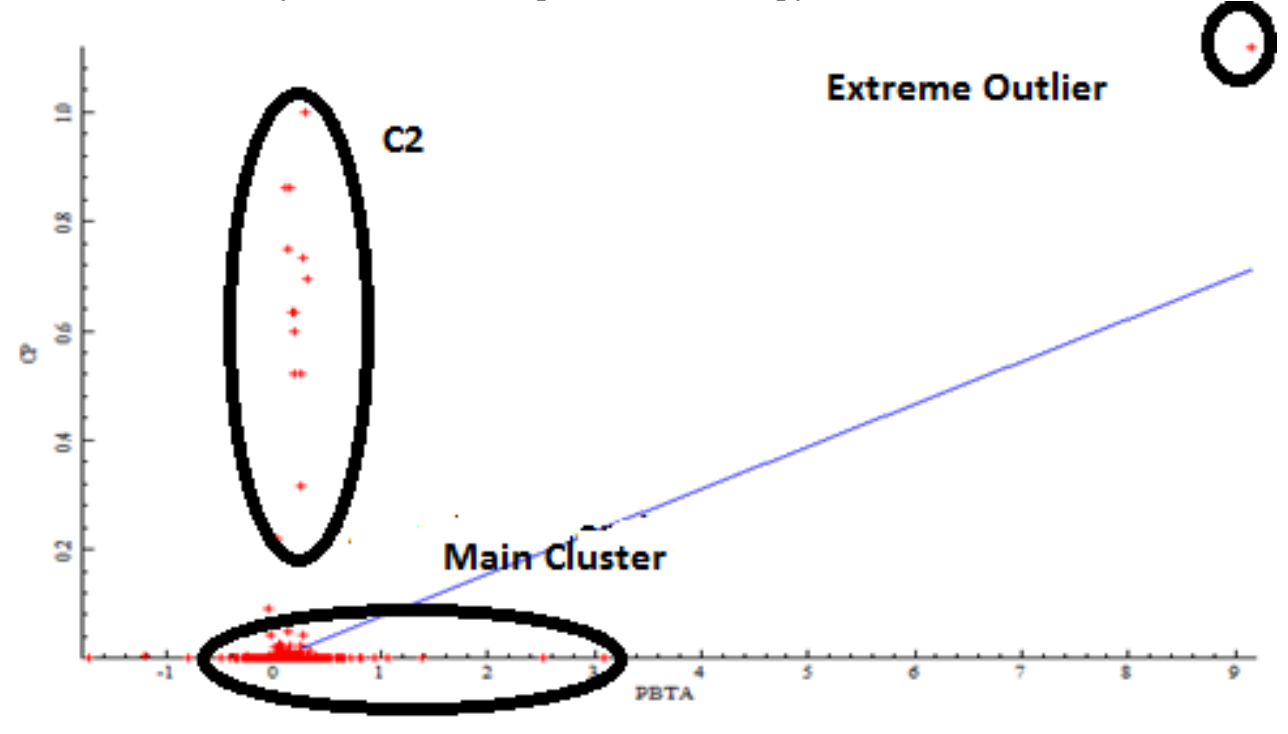

\subsubsection{Cash and Equivalent balances and Corporate Philanthropy}

Existing literature suggest that there is a positive relationship between Cash balances and $\mathrm{CP}$, but a simple regression run on all the data shows that there is a negative relationship between them. Plotting the data reveals clusters of firms. In the main cluster, $\mathrm{CP}$ remains at a low level while $\mathrm{CH}$ varies over a wide range - showing that $\mathrm{CH}$ does not exercise much influence on $\mathrm{CP}$. The cluster $\mathrm{C} 2$ shows widely ranging values of $\mathrm{CP}$ while $\mathrm{CH}$ remains approximately fixed at a low level, again showing no relationship between the two variables. In addition to these two clusters, there are three outliers that have high CP and large negative cash holdings. These three outliers have high leverage and force the regression line to show a negative relationship.

Figure 6.5 Cash and Equivalent balances $(\mathrm{CH})$ and Corporate Philanthropy $(\mathrm{CP})$

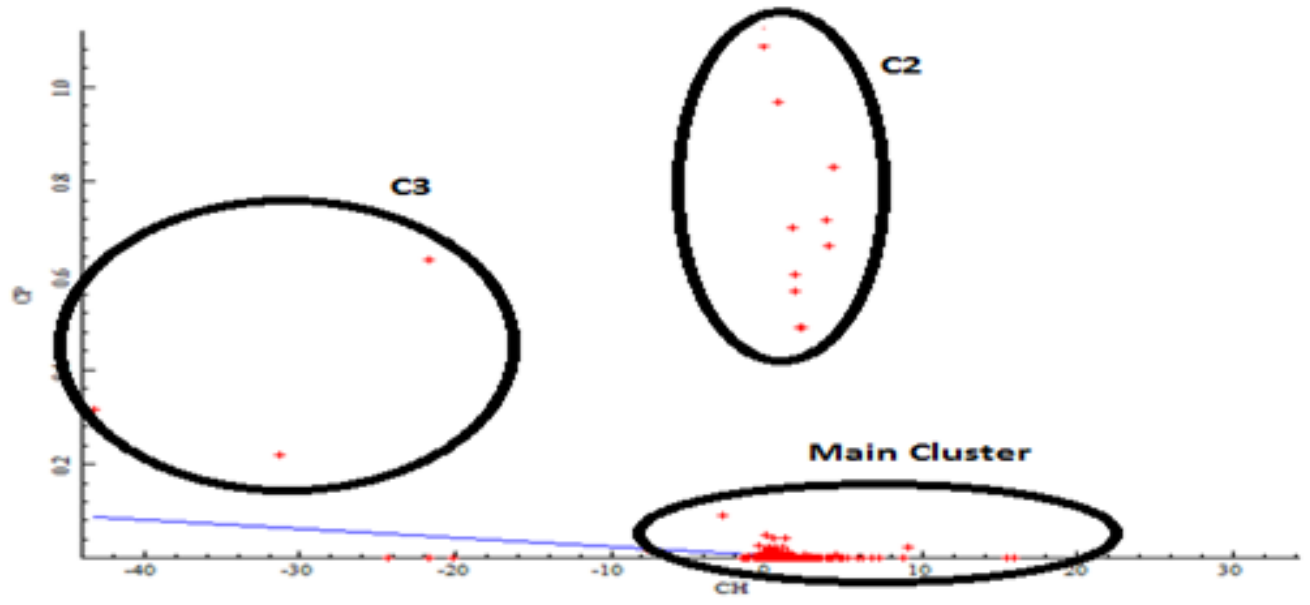

Once the outliers are removed from the analysis, it is clear that there is no relationship between $\mathrm{CH}$ and $\mathrm{CP}$. Hence, we can strongly reject the hypothesis H5 formulated by 
Brammer and Millington (2008) and Seifert et al. (2003). However, It would be worthwhile exploring the real world factors behind why some firms are behaving so differently.

\subsubsection{Prior Profitability and Corporate Philanthropy}

Moore and Robson (2002), Roberts (1992), and Arulampalam and Stoneman (1995) argued that prior profitability is positively correlated with CP. However, the regression line shows that there is weak positive relationship between $\mathrm{CP}$ and prior profitability, as pictured below.

Figure 6.6 Prior Profitability (LPBTA) and Corporate Philanthropy (CP)

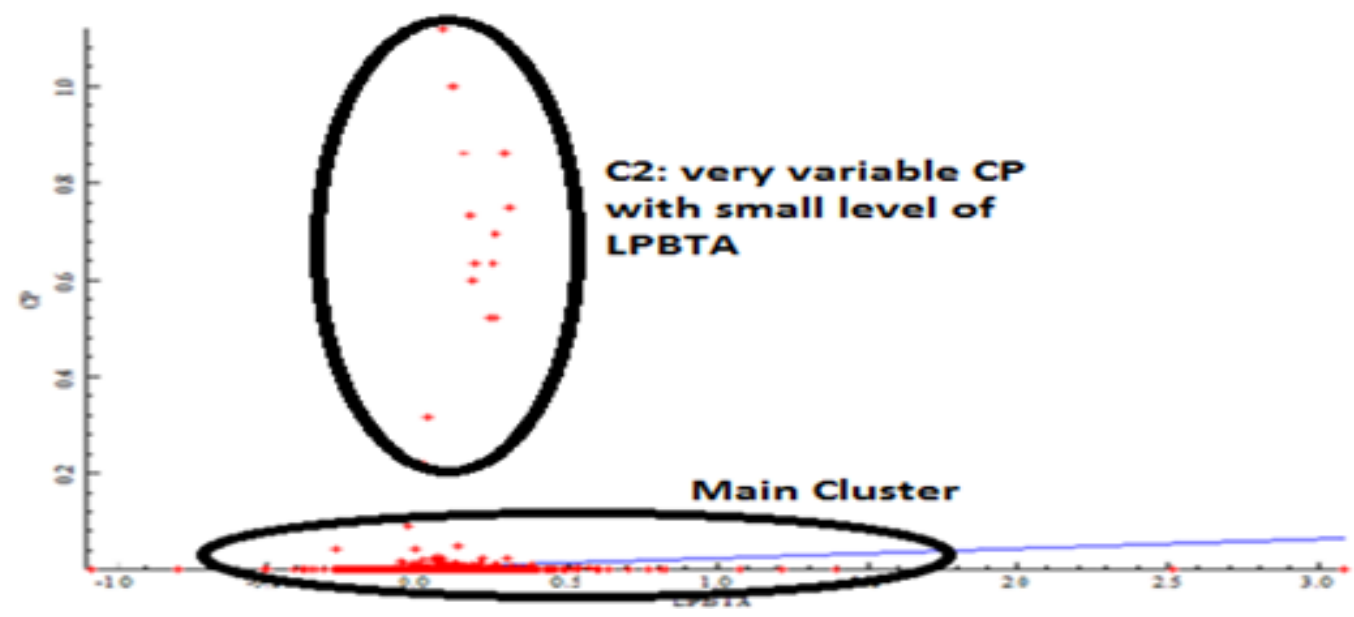

If we closely observe the scatter plot, then it seems that there are two type of firms, main cluster shows positive relationship, but $\mathrm{C} 2$ small cluster of firms shows very variable $\mathrm{CP}$ at very small level of profitability, there are also some extreme values near to the horizontal axis which shows very low $\mathrm{CP}$ at very extreme values of profitability. If we ignore these extreme values and the small cluster then it seems that data support the hypothesis H6 as formulated by Moore and Robson (2002), Roberts (1992) and others. However, it would be useful to explore the cluster $\mathrm{C} 2$, why these firms are behaving so differently.

\subsubsection{Dividend Payout and Corporate Philanthropy}

Previous research finds mixed results regarding the relationship between dividend payout and $\mathrm{CP}$; some researcher found positive relationship, while others find negative relationship. On the Pakistani firm data, the fitted line shows a positive relationship between DVD and CP; however, this is misleading.

A scatterplot of the data shows that there are two different clusters of firms. The main cluster along the $\mathrm{X}$-axis shows very wide range of DVD with no impact on CP. The second cluster of vertical outliers shows firms that have approximately similar small values of DVD but have very wide range of CP. There is one unusual observation in the data, which shows high DVD with high CP., which is pulling the fitted regression line upward. However, if we remove this outlier, then overall there is no relationship between DVD and CP. Hence we could reject the hypothesis $\mathrm{H} 7$ as formulated by Navarro (1988) as well as hypothesis H8 formulated by Brammer and Millington (2008). However, it would be worthwhile to explore why at very low level of dividents why some firms are making high donations. 
Figure 6.7 Dividend Payout (DVD) and Corporate Philanthropy (CP)

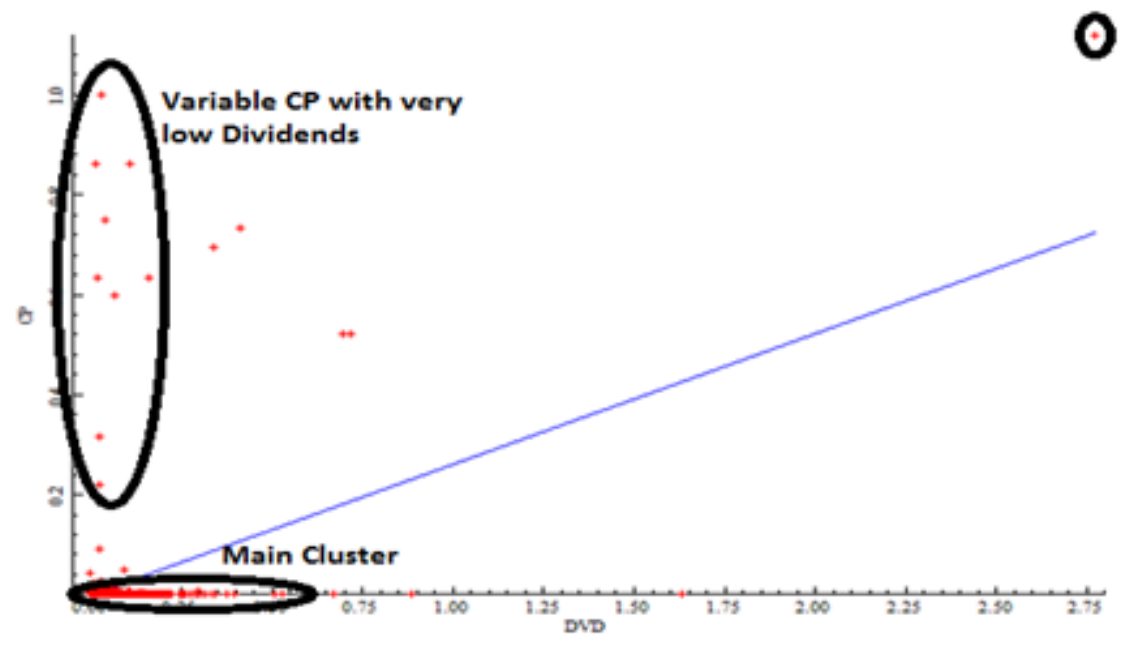

\subsubsection{Firm Size and Corporate Philanthropy}

Scatter plots shows that data is divided in to three clusters, main cluster near to horizontal axis shows that there is no relationship between firm size (SIZ) and CP - very variable firm size with very low $\mathrm{CP}$. But the second cluster $(\mathrm{C} 2)$ shows that there are some mid-sized firms have positive relationship with CP. Similarly, third cluster (C3) shows that there are some high sized firms with very variable CP. Data also shows that there is one outlier which shows that very small size firm is making very high CP. However, fitted regression line shows no relationship between $\mathrm{CP}$ and firm size as pictured below.

Figure 6.8 Firm Size (SIZ) and Corporate Philanthropy (CP)

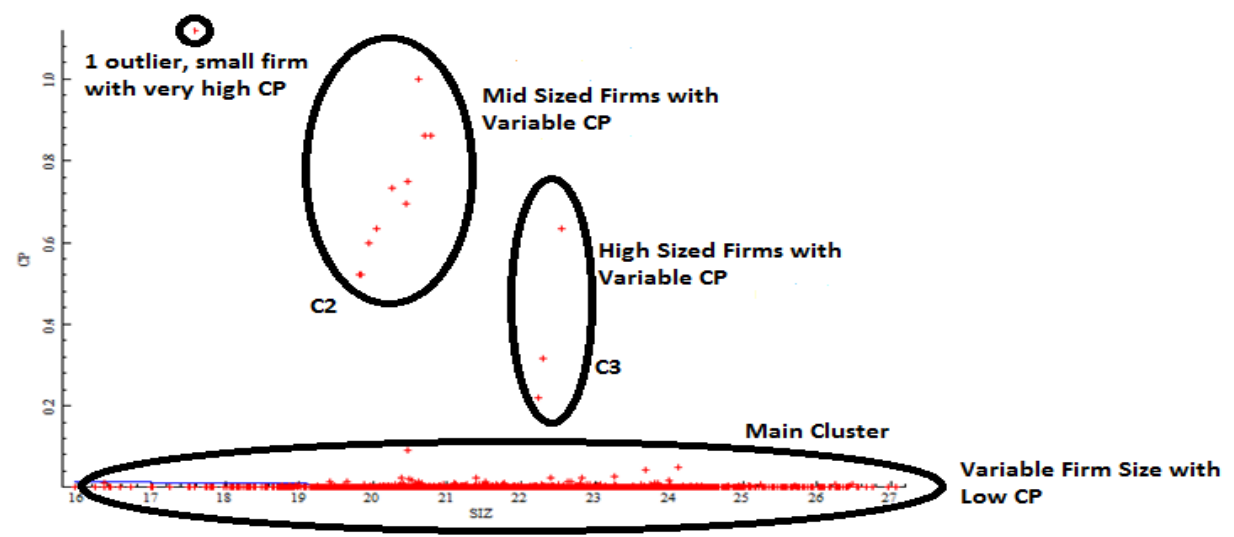

Scatter plot shows quite different types of behaviors regarding CP. It does not provide any clear support in favor of hypothesis H9, formulated by the Amato and Amato (2007), Brammer and Millington (2004, 2006), Carroll and Joulfaian (2005), Makki and Lodhi (2008) and others. however, it would be worth exploring why firms in $\mathrm{C} 2$ and $\mathrm{C} 3$ are behaving so differently, what are the real factors behind their behavior.

\subsubsection{Natural Disaster and Corporte Philanthropy}

Literature suggest that there is positive association between natural disaster and $\mathrm{CP}$. we have made line plot of CP from 2002 to 2011. Line plot shows that firms are making quite high donations in 2005 and in 2010. In 2005 there was a devastating earthquake in Kashmir, which 
put massive human and capital destruction, and it has been observed that firms are giving overall $0.1 \%$ of their sales, which was quite high from all time periods observed under study. Similarly in response to 2010 flood it has been observed that firms are giving $0.07 \%$ of their sales revenue as donation, this is comparatively less than 2005 but still quite high as compare to 2008 and 2009. Hence data provide strong support for the hypothesis H10, which we have formulated on the finding of Muller and Kräussl (2011).

Figure 6.9 Corporate Philanthropy Over the time period 2002-2011 ${ }^{14}$

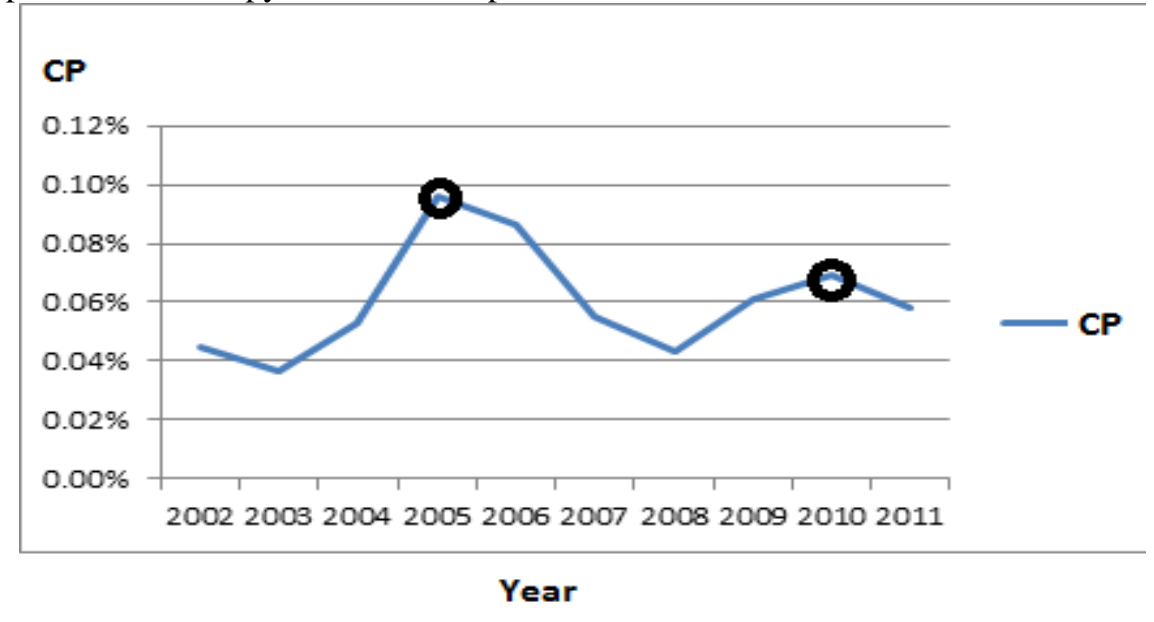

\subsection{Empirical Results and Discussion}

The present study has excluded all the minor clusters from the analysis and focused on main cluster to get the meaningful results. We have estimated Tobit model and REM and results are presented in the table 6-1.

\begin{tabular}{ccc}
\hline \hline Variables & REM & Tobit Model \\
\hline \multirow{2}{*}{ DVD } & -0.0002 & -0.0001 \\
& $(0.76)$ & $(0.93)$ \\
$F V I$ & 0.0002 & 0.0004 \\
SIZ & $(0.46)$ & $(0.40)$ \\
& $3.88 \mathrm{E}-05$ & $0.0002^{*}$ \\
LBI & $(0.22)$ & $(0.00)$ \\
& $-4.22 \mathrm{E}-05$ & -.0002 \\
PBTA & $(0.78)$ & $(0.40)$ \\
& $9.35 \mathrm{E}-05$ & 0.0002 \\
LIV & $(0.66)$ & $(0.50)$ \\
& $5.74 \mathrm{E}-06$ & $1.07 \mathrm{e}-07$ \\
CH & $(0.41)$ & $(0.99)$ \\
& $-5.58 \mathrm{E}-06$ & -.0000 \\
DNAD & $(0.78)$ & $(0.49)$ \\
& $0.000207 *$ & $0.0003^{*}$ \\
LPBTA & $(0.00)$ & $(0.00)$ \\
& $0.000412^{* *}$ & $0.0009^{* *}$ \\
$C$ & $(0.04)$ & $(0.01)$ \\
& -0.000326 & $-0.0035^{*}$ \\
& $(0.64)$ & $(0.00)$ \\
\hline \hline
\end{tabular}

Table 6.1 Estimation Results of Determinants of CP based on 221 firms over the period 2002-11. Notes: *,**, shows $p$ value $<0.01,<0.05$, respectively. We have used robust standard errors while estimating all models, and $p$ values are available in the parenthesis

\footnotetext{
${ }^{14}$ This graph is plotted after excluding all unusual values and minor clusters.
} 
From both estimation techniques we have found prior profitability and natural disaster has significant positive impact on CP. However, we have found no significance support for other measures of firm's financial position. Furthermore, Tobit model shows that firm size has also positive impact on $\mathrm{CP}$ i.e. large firms significantly contribute more as compare to small firms. But from REM we could not find any significant association between firm size and CP, this might be because in Tobit model we have truncated the data, only considered those firms that are making donation. However, study has found no significant impact of firm visibility, labor intensity, leverage, cash and equivalent balances and current profitability on $\mathrm{CP}$. These results are also consistent with the findings of exploratory analysis.

Hull and Rothenberg (2008), Brammer and Pavelin (2006) and McWilliams and Siegel (2001) have argued that firm visibility is positively related to $\mathrm{CP}$. However, we have found no significant evidence in case of Pakistan. Although, in west firm uses philanthropy for image creation, but in Pakistan for most of the firms, visibility is not an important factor, this might be because of societal differences. Many studies of Muslim philanthropy have shown that Muslims give more than comparable communities, in obedience to the strong and repeated commandments in the Quran to spend on others (ICM research poll 2012; Pew Research Survey, 2012, Najam 2007).

Brammer and Millington (2008) and Navarro (1988) believed that labor intensity is positively related to $\mathrm{CP}$. However, present study has found no evidence in support of labor intensity. In Pakistan unemployment rate is quite high and labor unions are not much strong and efficient, so this might be reasons that labor intensity is not playing any important role in influencing CP. However, one need to do an indepth analysis to check if it is really the case.

Brammer and Millington (2006, 2008), Seifert et.al. (2004), Wang et.al (2008) and others have argued that firms financial position is positively related to CP. In literature different indicators are used to measure firm's financial position. However, present study has found that only prior profitability is positively associated with $\mathrm{CP}$ and our results are consisitant with Arulampalam and Stoneman (1995), Moore and Robson (2002) and others. They argued that if firm earns high profit in last year then it can easily contribute in social issues. However, we did not find any significant association with cash and eqviualent balances, dividend payout and leverage.

Present study has found positive association between CP and firm size. It means large firms are donating more as compare to small firms, as they are facing less resource constraint. Makki and Lodhi (2008), Brammer and Millington (2004, 2006) and others have also found positive association between firm size and CP.

Muller and Kräussl (2011) has argued that firms behave generously at the time of natural disaster. Present study has also found significant evidence that firms respond to crises by accepting social responsibility and increasing Philanthropy. Hence, it would also be worth exploring to see the impact of Islamic norms on the patterns of $\mathrm{CP}$, and comparing it across cultures. Present study has reached to an interesting conclusion that firms are contributing more in response to disaster, and for majority of firms we have found no significant evidence that firms are using CP for image creation, except for a small cluster of firms. However, it is important to understand that standard econometrics can give clues. It can identify unusual behavior but it cannot guide us further to understand why some firms are behaving so 
unusual. To understand this, one need to visit those firms and investigate the reason behind their unusual behavior.

\section{CONCLUSION}

The present study has analyzed the relationship of firm size, firm visibility, labor intensity, firm's financial position and natural disaster with CP. Exploratory data analysis is very effective tool to understand data, to identify clusters and outliers. It tells us about patterns in the data, also provide clues to the real relationships. From exploratory data analysis we have learnt that for majority of firms, almost all hypotheses do not hold except for prior profitability and natural disaster. We have also learnt that there is small cluster of firms that are showing unusual behavior. From exploratory analysis we have seen that there are many firms which are not doing any donations. For this reason, we have used tobit model to truncate those firms that are not making any donations along with Standard panel data technique (Random effect model) and conclude that overall firm size, prior profitability and natural disaster significantly influence $\mathrm{CP}$.

From exploratory analysis, we have seen that there is small cluster of firms which shows unusual behavior. however, standard econometric techniques cannot guide us further why those firms are behaving so unusual, what are the reasons behind this. Econometric tools just provide clues about the real world. However, to understand real world one needs to do shoe leather.

\section{REFERENCES}

Abzug, R. and N. J. Webb (1996). Rational and extra-rational motivations for corporate giving: Complementing economic theory with organization science. NYL Sch. L. Rev., 41,1035 .

Adams, M. and P. Hardwick (1998). An analysis of corporate donations: United Kingdom evidence. Journal of Management Studies, 35 (5), 641-654.

Afshar, T. (2012). Corporate Philanthropy in the UK and US: The impact of cycles, Strategy and CEO Succession (Doctoral dissertation, University of London).

Amato, L. H. and C. H. Amato (2007). The effects of firm size and industry on corporate giving. Journal of Business Ethics, 72 (3), 229-241.

Arulampalam, W. and P. Stoneman (1995). An investigation into the givings by large corporate donors to UK charities, 1979-86. Applied Economics, 27 (10), 935-945.

Brammer, S. and A. Millington (2004). The development of corporate charitable contributions in the UK: A stakeholder analysis. Journal of Management Studies, 41 (8), 1411-1434.

Brammer, S. and A. Millington (2006). Firm size, organizational visibility and corporate philanthropy: an empirical analysis. Business Ethics: A European Review, 15 (1), 6-18.

Brammer, S. and A. Millington (2008). Does it pay to be different? An analysis of the relationship between corporate social and financial performance. Strategic Management Journal, 29 (12), 1325-1343. 
Brammer, S. and S. Pavelin (2006). Corporate reputation and social performance: The importance of fit. Journal of Management Studies, 43 (3), 435-455.

Brown, M. S., Chin, W. H. and Rooney, P. (2004) Estimating Corporate Charitable Giving For Giving USA, Series, Research Report, Indiana University Center on Philanthropy.

Brown, W. O., E. Helland and J. K. Smith (2006). Corporate philanthropic practices. Journal of corporate finance, 12 (5), 855-877.

Campbell, D., G. Moore and M. Metzger (2002). Corporate philanthropy in the UK 19852000 some empirical findings. Journal of Business Ethics, 39 (1-2), 29-41.

Carroll, R. and D. Joulfaian (2005). Taxes and corporate giving to charity. Public Finance Review, 33 (3), 300-317.

Chai, D. H. (2010). Firm Ownership and Philanthropy. Centre for Business Research, University of Cambridge.

Friedman, M. (1970). The Social Responsibility Of Business Is To Increase Its Profits. 217 223. Website. http://www.colorado.edu/studentgroups/libertarians/issues/friedman-socresp-business.html (accessed Nov 12, 2013)

Godfrey, P. C., C. B. Merrill and J. M. Hansen (2009). The relationship between corporate social responsibility and shareholder value: An empirical test of the risk management hypothesis. Strategic Management Journal, 30 (4), 425-445.

Grullon, G., G. Kanatas and J. P. Weston (2004). Advertising, breadth of ownership, and liquidity. Review of Financial Studies, 17 (2), 439-461.

Gujarati, D. N. (2009). Basic econometrics. Tata McGraw-Hill Education.

Gupta, S. (1996). Taxes and corporate charity: empirical evidence from micro-level panel data. National Tax Journal, 49 (2), 193-213.

Hillman, A. J. and G. D. Keim, (2001). Shareholder value, stakeholder management, and social issues: what's the bottom line? Strategic Management Journal, 22 (2), 125-139.

Hsiao, C. (2003). Analysis of Panel Data (Econometric Society Monographs). Cambridge: Cambridge University Press.

Hull, C. E. and S. Rothenberg (2008). Firm performance: The interactions of corporate social performance with innovation and industry differentiation. Strategic Management Journal, 29 (7), 781-789.

Johnson, R. A. and D. W. Greening, (1999). The effects of corporate governance and institutional ownership types on corporate social performance. Academy of management Journal, 42 (5), 564-576. 
Makki, M. A. M. and S. A. Lodhi (2008). Determinants of corporate philanthropy in Pakistan. Pakistan Journal of Commerce and Social Sciences, 1, 17-24.

McWilliams, A. and D. Siegel (2001). Corporate social responsibility: A theory of the firm perspective. Academy of management review, 26 (1), 117-127.

Moore, G. and A. Robson (2002). The UK supermarket industry: an analysis of corporate social and financial performance. Business Ethics: A European Review, 11 (1), 25-39.

Muller, A. and R. Kräussl (2011). Doing good deeds in times of need: A strategic perspective on corporate disaster donations. Strategic Management Journal, 32 (9), 911-929.

Najam, A. (2007). Portrait of A Giving Community: Philanthropy by the Pakistani-American Diaspora. Harvard: Harvard University Press.

Navarro, P. (1988). Why Do Corporations Give to Charity? The Journal of Business, 61(1), $65-93$

Orlitzky, M., F. L. Schmidt and S. L. Rynes (2003). Corporate social and financial performance: A meta-analysis. Organization studies, 24 (3), 403-441.

Porter, M. E. and M. R. Kramer (2002). The competitive advantage of corporate philanthropy. Harvard business review, 80 (12), 56-68.

Roberts, R. W. (1992). Determinants of corporate social responsibility disclosure: an application of stakeholder theory. Accounting, Organizations And Society, 17 (6), 595 612.

Schnietz, K. E. and M. J. Epstein (2005). Exploring the financial value of a reputation for corporate social responsibility during a crisis. Corporate Reputation Review, 7 (4), 327 345 .

Seifert, B., S. A. Morris and B. R. Bartkus (2003). Comparing big givers and small givers: Financial correlates of corporate philanthropy. Journal of Business Ethics, 45 (3), 195211.

Seifert, B., S. A. Morris and B. R. Bartkus (2004). Having, giving, and getting: Slack resources, corporate philanthropy, and firm financial performance. Business and Society, 43 (2), 135-161.

Thompson, J. K. and J. N. Hood (1993). The practice of corporate social performance in minority-versus nonminority-owned small businesses. Journal of Business Ethics, 12 (3), 197-206.

Tilcsik, A. and C. Marquis (2013). Punctuated Generosity How Mega-events and Natural Disasters Affect Corporate Philanthropy in US Communities. Administrative Science Quarterly, 58 (1), 111-148.

Tse, T. (2011). Shareholder and stakeholder theory: after the financial crisis. Qualitative Research in Financial Markets, 3 (1), 51-63. 
Ullmann, A. A. (1985). Data in search of a theory: a critical examination of the relationships among social performance, social disclosure, and economic performance of US firms. Academy of management review, 10 (3), 540-557.

Van Beurden, P. and T. Gössling (2008). The worth of values-a literature review on the relation between corporate social and financial performance. Journal of Business Ethics, $82(2), 407-424$.

Waddock, S. A. and S. B. Graves (1997). The corporate social performance. Strategic Management Journal, 8 (4), 303-319.

Wang, H., J. Choi and J. Li (2008). Too little or too much? Untangling the relationship between corporate philanthropy and firm financial performance. Organization Science, 19 (1), 143-159.

Williams, R. J. and J. D. Barrett (2000). Corporate philanthropy, criminal activity, and firm reputation: is there a link? Journal of Business Ethics, 26 (4), 341-350. 